\title{
HUSBAND'S SUPPORT PARTICIPATION FOR PREGNANT WOMEN THROUGH VIDEO IN FE TABLET CONSUMPTION
}

\author{
Utami Dewi ${ }^{1}$, Fidyah Aminin ${ }^{2}$, Nurniati, TR ${ }^{1}$, Vina Jayanti ${ }^{3}$ \\ ${ }^{1,2,3}$ D3 Midwifery Study Program, Health Polytechnic of the Ministry of Health, Tanjungpinang
}

\section{INFORMASI ARTIKEL:}

\section{Riwayat Artikel:}

Tanggal diterima: September 2020

Tanggal di revisi: September 2020

Tanggal di Publikasi: Oktober 2020

Key Word : video, husband's support, anemia, iron tablet supplementation

\begin{abstract}
A B S T R A C T
The Indonesian government has initiated the provision of iron tablet supplementations to pregnant women. However, the lack of support from the family, especially husbands, in controlling the consumption of these tablets has resulted in the government program not being able to achieve the target set. This quasi experimental study used a pre-posttest model with a control group design. In this study, there were two groups, namely the treatment group and the control group who were given a questionnaire before and after the intervention. The treatment group was given intervention in the form of a husband's mentoring video, while the control group received services in the form of health education with sample size for each group at 47 persons. The results of the analysis showed there were more respondents who experienced the increased knowledge, i.e., 30 persons when compared to those in the control group by only 16 persons. It was then concluded that the use of video to increase the participation of husbands as a companion to remind the wife to consume iron supplementation was significant.
\end{abstract}

resulting in low birth weight and increased mortality.[6]

Pregnant women are a target group that needs special attention in terms of nutrition because they are a group that is vulnerable to nutritional problems. One of the nutritional problems that often occur in pregnant women is anemia.[1] Pregnant women are said to experience pregnancy anemia if the hemoglobin $(\mathrm{Hb})$ level is less than $11 \mathrm{~g} / \mathrm{dL}$.[2] Anemia in pregnancy has a harmful impact on both the mother and the fetus. Anemia in pregnant women can increase the risk of postpartum hemorrhage.[3]

Anemia that occurs early in pregnancy can also put you at risk for prematurity.[4] Anemia that often occurs in pregnant women is iron deficiency anemia happening worldwide.[5] Given the harmful effects, it is necessary to prevent anemia by giving iron tablets to pregnant women. Iron deficiency anemia is an important cause of maternal death during childbirth, and during the puerperium as a result of complications. Anemia during pregnancy can also affect fetal growth,

${ }^{*}$ Korespondensi:

The Indonesian government has made efforts to control anemia, including by providing Iron supplement tablets to pregnant women. Iron tablets have also been distributed through the Puskesmas and Posyandu. The results of the 2010 Riskesdas showed that $80.7 \%$ of women aged 10-59 years had received iron supplementation. In 2015 in Indonesia, pregnant women who received iron supplementation were $85.17 \%$. This means that it has increased even though it has not been optimal from 2010. Meanwhile, in Riau Islands Province, pregnant women who received the supplementation in 2015 were $79.07 \%$. From this information, the achievement of the Riau Islands Province was still below the national achievement.[7] Pregnant women who received iron supplementation in 2016 in Tanjungpinang City were $89.8 \%$ while the incidence of anemia in pregnant women in this city in the same year was $12.21 \%$.[8]

Through the iron supplement program, it is expected to reduce the incidence of anemia in 
pregnant women in Indonesia. However, the results were not satisfactory, as seen from the high prevalence. Compliance in undergoing a treatment program can involve family support. However, so far there has been no special companion for the consumption of iron tablets, which monitors the consumption of iron tablets. Health behavior in pregnant women is influenced by several factors, namely predisposing factors such as knowledge, enabling (enabling), which includes the availability of facilities and infrastructure or health facilities, the last is the reinforcing factor including family support and health workers (Astuti, 2016).

Provision of information about anemia in pregnancy and assistance by husbands to pregnant women when consuming iron tablets have been proven to increase the husband's knowledge and attitudes in providing assistance to prevent anemia in pregnant women. Therefore, conveying information to the husbands of pregnant women is important for the success of assisting pregnant women in consuming iron tablets. Information about anemia in pregnant women and assistance by husbands when pregnant women consume iron tablets in Indonesia still uses leaflets (Masifah et al., 2013) and modules (Aminin et al., 2018).

The ability of health workers is still based on outreach activities with lectures, while audiovisual health promotion is still limited. Based on a preliminary study conducted on January 7, 2019 at the Community Health Center and Independently Practicing Midwives in Tanjungpinang City, the following information was obtained: $100 \%$ of respondents had smartphones equipped with internet facilities. However, those $100 \%$ of respondents had never received health education through social media or audio-visual media from health workers. They stated that they preferred watching videos rather than reading modules or leaflets, and at 5 Independently Practicing Midwives in Tanjungpinang City, all of them did not have audio-visual media as a means of health promotion. From this background, it is important to conduct research on the effect of health education using audio-visual media on social media on the knowledge of husbands of pregnant women about anemia prevention, as the pregnant women accompanion to consume iron tablets in pregnancy.

\section{METHOD}

This quasi experimental study used a preposttest model with a control group design. In this study, there were two groups, namely the treatment group and the control group who were given a questionnaire before and after the intervention. The treatment group was given intervention in the form of a husband's mentoring video, while the control group received services in the form of health education at the Independently Practicing Midwife. To determine the change in knowledge, re-measurement was carried out after 7 days using the same questionnaire sheet (post-test). The data were collected twice, namely during the pre-test and post-test. The instrument used in the data collection process was a structured questionnaire to determine the characteristics of respondents and knowledge.

The population in this study was all husbands of pregnant women in Tanjungpinang City. The samples in this study were the husbands of pregnant women who checked themselves into the Independently Practicing Midwives. Husbands of pregnant women who checked themselves in to Clinic A were the sample of the treatment group, while husbands of pregnant women who checked themselves in to Clinic B were samples of the control group. Both groups had to meet the inclusion and 
exclusion criteria. The sampling technique used was simple random sampling on the grounds that the population was considered homogeneous. The number of samples for each group was set at 47 people. Inclusion criteria included husbands of pregnant women who had a smartphone, were present during the pre-test and post-test, were willing to be respondents, were able to read and write, were physically and spiritually healthy, and whome the wife obtained by the designated midwives. For the exclusion criteria, the criteria were husbands of pregnant women who had received training on anemia during pregnancy and worked as health workers or health cadres. The sample count also included drop out, namely not using the video according to the instructions given (treatment group) and absent from the ANC program at the next visit with pregnant women (control group).

The data analysis used in this study was carried out in stages including:

a. Univariate

Data analysis used univariate analysis to describe the characteristics of respondents, such as education and maternal occupation. Each variable was calculated the mean, standard deviation, median, and range.

\section{b. Bivariate}

Prior to the statistical test, the data normality test was carried out. The test used was the Shapiro-Wilk test, because the number of respondents in this study was less than 50 people in each group. The parametric test used was Wilcoxon.

This research was conducted after obtaining a letter of ethical eligibility from the health research ethics commission of the Health Ministry of Health Riau Polytechnic. Researchers applied three basic principles of research ethics, namely: Respect for human dignity (Respect to person), do good
(Beneficence), and the principle of justice (Justice).

\section{RESULT AND DISCUSSION}

\section{Validation and Video Trial Results}

In the process of compiling this video, an assessment of the feasibility of the video was carried out by experts, namely anemia prevention material experts and video experts. The results showed that all aspects of the assessment received good scores, which means that this video was suitable for use. In addition, a video trial was conducted on 30 respondents prior to data collection. Based on video testing of 30 respondents, the video was interesting and easy to understand. This video contained information about anemia and how to prevent it as well as the assistance that the husband of pregnant women took when taking iron supplementations

\section{Univariate Analysis}

\section{Characteristics}

Respondents in this study were 47 people in the treatment group and 47 people in the control group. The characteristics of the respondents are shown in Table 1.

Table 1

Distribution of respondent characteristics based on occupation and education

\begin{tabular}{lcc}
\hline \multicolumn{1}{c}{ Characteristics } & Frequency & Persentase (\%) \\
\hline Treatment Group & & \\
Occupation & & \\
High & 45 & 95,7 \\
Low & 2 & 4,3 \\
Education & & \\
High & 36 & 76.5 \\
Low & 11 & 23.5 \\
\hline Control Group & & \\
Occupation & & \\
High & 40 & 85,1 \\
Low & 7 & 14,9 \\
Education & & \\
High & 6 & 12,8 \\
Low & 31 & 87,2 \\
\hline
\end{tabular}


Most of the respondents (95.7\%) in the treatment group had high education and most of the respondents $(76.2 \%)$ had high status jobs. While in the control group, most of the respondents $(87.2 \%)$ had low education and most of the respondents $(85.1 \%)$ had high status jobs.

\section{Knowledge}

Table 2 illustrates the distribution of knowledge of the treatment group respondents that all respondents had an increase in the score of knowledge on each item but in question no.12, which is about the Iron Tablet provision program to pregnant women; there was no increase in the respondent's knowledge.

\section{Table 2}

The distribution of respondents' answers to the treatment group before and after getting health education using video

\begin{tabular}{lcccc}
\hline \multicolumn{1}{c}{ Question } & \multicolumn{2}{c}{ Before } & \multicolumn{2}{c}{ Afetr } \\
\cline { 2 - 5 } & $\begin{array}{c}\text { Correct } \\
\text { Answer } \\
\text { Frequency }\end{array}$ & $\begin{array}{c}\text { Persentase } \\
\text { (\%) }\end{array}$ & $\begin{array}{c}\text { Correct } \\
\text { Answer } \\
\text { Frequency }\end{array}$ & $\begin{array}{c}\text { Persentase } \\
\text { (\%) }\end{array}$ \\
\hline $\begin{array}{l}\text { Definition of } \\
\text { anemia }\end{array}$ & 26 & 55.3 & 40 & 85.1 \\
$\begin{array}{l}\text { Categories of } \\
\text { anemia and signs of }\end{array}$ & 43 & 91.4 & 45 & 95.7 \\
anemia symptoms & 32 & 68.1 & 41 & 87.2 \\
$\begin{array}{l}\text { Prevention of } \\
\text { Anemia in pregnant }\end{array}$ & 43 & 91.4 & 47 & 91.4 \\
women & 31 & 65.9 & 40 & 85.1 \\
The danger of & 33 & 70.2 & 39 & 82.9 \\
anemia for pregnant & 32 & 68.1 & 42 & 89.4 \\
women & 34 & 72.3 & 44 & 93.6 \\
Iron Tablets & 30 & 63.8 & 43 & 91.5 \\
$\begin{array}{l}\text { Program for giving } \\
\text { iron tablets to }\end{array}$ & 39 & 82.9 & 45 & 95.7 \\
pregnant women & 41 & 87.2 & 47 & 100 \\
Iron Tablets side & 41 & 87.2 & 46 & 97.8 \\
effects and how to & 34 & 72.3 & 45 & 95.7 \\
deal with them & 29 & 61.7 & 39 & 82.9 \\
$\begin{array}{l}\text { How to consume } \\
\text { Iron Tablets }\end{array}$ & 40 & 85.1 & 45 & 95.7 \\
$\begin{array}{l}\text { The role of husband } \\
\text { or family in }\end{array}$ & 39 & 82.9 & 36 & 76.6 \\
accompanying & 35 & 74.5 & 30 & 63.8 \\
pregnant women to & 40 & 80.8 & 44 & 93.6 \\
consume Iron & & 85.1 & 44 & 93.6 \\
Tablets & 43 & 91.4 & 46 & 97.8 \\
\hline & & & & \\
\hline
\end{tabular}

Table 4 illustrates the distribution of knowledge of the control group respondents; all respondents had an increase in their knowledge score on each item. When compared between the treatment group and the control group, prior knowledge of health education was given, the control group had a higher knowledge scorethan the treatment group.

\section{Table 3}

The distribution of respondents' answers to the control group before and after getting health education using video

\begin{tabular}{|c|c|c|c|c|}
\hline \multirow[b]{2}{*}{ Question } & \multicolumn{2}{|c|}{ Before } & \multicolumn{2}{|c|}{ After } \\
\hline & $\begin{array}{l}\text { Correct } \\
\text { Answer } \\
\text { Frequency }\end{array}$ & $\begin{array}{l}\text { Persentase } \\
(\%)\end{array}$ & $\begin{array}{l}\text { Correct Answer } \\
\text { Frequency }\end{array}$ & Persentase (\%) \\
\hline Definition of anemia & 33 & 70.2 & 47 & 100 \\
\hline \multirow{3}{*}{$\begin{array}{l}\text { Categories of anemia } \\
\text { and signs of anemia } \\
\text { symptoms }\end{array}$} & 39 & 82.9 & 46 & 97.8 \\
\hline & 32 & 68 & 46 & 97.8 \\
\hline & 43 & 91.4 & 46 & 97.8 \\
\hline \multirow{2}{*}{$\begin{array}{l}\text { Prevention of Anemia } \\
\text { in pregnant women }\end{array}$} & 34 & 72.3 & 45 & 95.7 \\
\hline & 35 & 74.4 & 44 & 93.6 \\
\hline \multirow{2}{*}{$\begin{array}{l}\text { The danger of anemia } \\
\text { for pregnant women }\end{array}$} & 38 & 80.8 & 47 & 100 \\
\hline & 34 & 72.3 & 44 & 93.6 \\
\hline \multirow{2}{*}{ Iron Tablets } & 38 & 80.8 & 43 & 91.4 \\
\hline & 43 & 91.4 & 47 & 100 \\
\hline \multirow{4}{*}{$\begin{array}{l}\text { Program for giving iron } \\
\text { tablets to pregnant } \\
\text { women } \\
\text { Iron Tablets side effects } \\
\text { and how to deal with } \\
\text { them }\end{array}$} & 40 & 85.1 & 47 & 100 \\
\hline & 40 & 85.1 & 47 & 100 \\
\hline & 39 & 82.9 & 46 & 97.8 \\
\hline & 36 & 76.5 & 45 & 95.7 \\
\hline \multirow{2}{*}{$\begin{array}{l}\text { How to consume Iron } \\
\text { Tablets }\end{array}$} & 37 & 78.7 & 47 & 100 \\
\hline & 29 & 61.7 & 37 & 78.7 \\
\hline \multirow{4}{*}{$\begin{array}{l}\text { The role of husband or } \\
\text { family in accompanying } \\
\text { pregnant women to } \\
\text { consume Iron Tablets }\end{array}$} & 30 & 63.8 & 33 & 70.2 \\
\hline & 44 & 93.6 & 47 & 100 \\
\hline & 46 & 97.8 & 47 & 100 \\
\hline & 45 & 95.7 & 47 & 100 \\
\hline
\end{tabular}

\section{Bivariate Analysis}

\section{The effect of video on respondents' knowledge}

The results of the analysis in table 4 show that in the treatment group after receiving health education using video there were 5 people with lower knowledge outcomes than before being given health education using video, 12 were regular and 30 experienced an increase. There was a significant difference in knowledge before and after in the treatment group with $\mathrm{p}$ value $<0.05$ (0.000). In the control group after receiving health education without using video, there were 5 people with lower knowledge outcomes than before being given health education using video, 26 remained and 16 experienced an increase. 
There was a significant difference in knowledge before and after in the control group with $\mathrm{p}$ value $<0.05(0.000)$.

Table 4

Differences in knowledge in the control group and the treatment group

\begin{tabular}{|c|c|c|}
\hline \multirow[b]{2}{*}{ Knowledge } & \multicolumn{2}{|c|}{ Group } \\
\hline & $\begin{array}{c}\text { Treatment } \\
(n=47)\end{array}$ & $\begin{array}{l}\text { Control } \\
(\mathrm{n}=47)\end{array}$ \\
\hline 1. Negative Rank & 5 & 5 \\
\hline Mean Rank & 6 & 8.10 \\
\hline 2. Ties & 12 & 26 \\
\hline 3. Positive Rank & 30 & 16 \\
\hline Mean Rank & 20 & 17.52 \\
\hline p-value & $0.000 *$ & $0.000 *$ \\
\hline
\end{tabular}

\section{Differences in respondents' knowledge before and after being given the video}

The results of the analysis in table 4 show that there is a difference in knowledge before and after in the treatment group with $p$ value $<0.05$ (0.000), as well as the control group with a $\mathrm{p}$ value $<0.05(0.000)$. The treatment group and the control group both received information about anemia prevention and assistance for pregnant women to consume iron tablets even though the media and methods used were different, so it was possible for the two groups to experience an increase in knowledge after receiving information about anemia prevention. However, the increase in knowledge was different. The treatment group after receiving health education using video contained 5 people with lower knowledge outcomes than before being given health education using video, 12 were regular and 30 experienced an increase. Whereas in the control group after receiving health education without using video, there were 5 people with lower knowledge outcomes than before being given health education without using video, 26 remained and 16 experienced an increase.

Information about anemia prior to intervention can be obtained from various sources. Knowledge about the causes of anemia, prevention and management of anemia can be obtained from hospitals or other health facilities. The video provided to respondents gave access for respondents to learn health knowledge about anemia, its prevention and assistance for pregnant women to consume iron tablets. Health literature, such as videos, can accommodate one's achievement in understanding health promotion, prevention and management of a disease,[12] including anemia in pregnant women.

The video presentation accompanied by instructional and animated instructions aroused great curiosity. Curiosity and a pleasant learning atmosphere are aspects of creating high motivation to learn.[13] In this current research, the curiosity causing the senses involved are not limited to the visual senses, but also the sense of hearing. The more senses involved in learning, the more information that will be obtained, so that it affects the higher understanding.

Interactive video providing individual control over random access to content can lead to better learning outcomes and higher learning satisfaction. Videos can improve the quality of learning achievement. The use of video as an educational intervention is an approach that has proven effective in many fields of health.[14] Video education has been shown to be superior to written information in terms of patient satisfaction and information retrieval. Multimedia materials have been used extensively to communicate health-related messages to the general population, increase patient knowledge about certain diseases, and assist in the management of specific diseases. Video has been widely applied before in 
various aspects and it was also shown in this research.

\section{CONCLUSION}

There was an effect of the video on the husband's knowledge of anemia in the treatment group. Therefore, the husbands were more aware of the iron tablet supplementation for their spouse in the prevention of anemia.

\section{REFERENCE}

Barragán-Ibañez, G., Santoyo-Sánchez, A., \& Ramos-Peñafiel, C. O. (2016). Iron deficiency anaemia. Revista Médica Del Hospital General de México, 79(2), 88-97. doi:10.1016/j.hgmx.2015.06.008

Wahed, A., \& Dasgupta, A. (2015). Red Blood Cell Disorders. Hematology and Coagulation, 31-53. doi:10.1016/b978-0-12-8002414.00003-6

Lisonkova, S., Mehrabadi, A., Allen, V. M., Bujold, E., Crane, J. M. G., Gaudet, L., ... Joseph, K. S. (2016). Atonic Postpartum Hemorrhage: Blood Loss, Risk Factors, and Third Stage Management. Journal of Obstetrics and Gynaecology Canada, 38(12), 1081-1090.e2. doi:10.1016/j.jogc.2016.06.014

Alan, S., \& Arsan, S. (2015). Prevention of the anaemia of prematurity. International Journal of Pediatrics and Adolescent Medicine, 2(3-4), 99-106. doi:10.1016/j.ijpam.2015.10.001

Georgieff, M. K. (2020). Iron Deficiency in Pregnancy. American Journal of Obstetrics and

Gynecology. doi:10.1016/j.ajog.2020.03.006

Kumari, S., Garg, N., Kumar, A., Guru, P. K. I., Ansari, S., Anwar, S., ... Sohail, M. (2019). Maternal and severe anaemia in delivering women is associated with risk of preterm and low birth weight: A cross sectional study from Jharkhand, India. One Health, 100098. doi:10.1016/j.onehlt.2019.100098
Pusdatin (2016) Situasi Gizi di Indonesia. Jakarta.

Health Profile of Tanjungpinang City, 2016.

Astuti, D. (2016) 'Faktor-faktor yang berhubungan dengan kejadian anemia pada ibu hamil di Puskesmas Undaan Lor Kabupaten Kudus', in, pp. 123-131.

Masifah, S. et al. (2013) 'Efektifitas Pelatihan Media Audio-Visual Terkait Anemia Ibu Hamil Dalam Peningkatan Kompetensi petugas Penyuluh Kesehatan Di Kabupaten Banyumas', pp. 12-22.

Aminin, F. et al. (2018) Modul Pendampingan Ibu Hamil Sebagai Salah Satu Inovasi Pencegahan Anemia Pada Kehamilan. Tanjungpinang.

Sørensen, K., Van den Broucke, S., Fullam, J., Doyle, G., Pelikan, J., ... Brand, H. (2012). Health literacy and public health: A systematic review and integration of definitions and models. BMC Public Health, 12(1). doi:10.1186/1471-2458-12-80

Kidd, C., \& Hayden, B. Y. (2015). The Psychology and Neuroscience of Curiosity. Neuron, 88(3), 449460. doi:10.1016/j.neuron.2015.09.010

Ferguson, L. A. (2012). Implementing a Video Education Program to Improve Health Literacy. The Journal for Nurse Practitioners, $8(8)$, e17-e22. doi:10.1016/j.nurpra.2012.07.025 